\title{
A study on relationship between assets' objectivity, ROA, ROE and ownership ratio with liquidity cycle
}

\author{
Hassan Ghodrati, Hosein Jabbari and Mohammad Javad Esfandyari*
}

Department of Management and Accounting, Kashan Branch, Islamic Azad University, Kashan, Iran

\begin{tabular}{l}
\hline C H R O N I C L E \\
\hline Article history: \\
Received December 28, 2013 \\
Accepted 10 April 2014 \\
Available online \\
April 172014 \\
\hline Keywords: \\
Tehran Stock Exchange \\
Assets objectivity \\
ROA \\
ROE
\end{tabular}
\begin{abstract}
A B S T R A C T
This paper studies the effects of cash conversion cycle (CCC) and size of selected firms listed on Tehran Stock Exchange (TSE) on four variables including return of assets, return of equities, tangible assets and equity multiplier. The study selects a sample of 105 firms listed on TSE and divides them into two groups of big and small sized companies over the period 2008-2012. Using a regression analysis, the study confirmed a meaningful relationship between different variables. In other words, in our survey, CCC and size negatively influence on tangible assets, they positively influence on equity multiplier as well as ROA but the effects of CCC and size on ROE for small and big firms are mixed.
\end{abstract}

\section{Introduction}

Cash rotation starts when a firm turns cash to pay for raw materials and continues until it re-charges from the sale of goods. The duration of cash flow period is calculated based on the average period that the money exists as commodity funds plus the average recovery period minus payment deadline of payable accounts (Brigham \& Houston, 2011). Over time, the cash cycle has been one of the determinants for the return on assets (ROA) and the return on the equities (ROE). Production involves the implementation of cash when firms first purchase raw materials to produce products, and then transform them into commodities. Therefore, receivable accounts or notes increase through selling the manufactured items, and cash flow period terminates by debt collection. Cash conversion cycle in big and small companies can be the same or different from each other. Assets objectivity can also be regarded as a capital backing for the company and this must always be kept in mind that a firm's management tries to maximize return on assets, return on equity, and equity multiplier of the

\footnotetext{
*Corresponding author.

E-mail addresses: Javad hs2005@yahoo.com (M. J. Esfandyari) 
company. In this context, cycle cash and high-speed cash conversion can account for the greatest factors influencing the return on assets and return on equity.

Another managerial goal of any profitable organization is to balance between available cash and cash required. The management is responsible to plan how to meet cash requirements and the necessary funds. Financial managers have to perform tasks to provide required liquidity to run the business activities. One of the tasks for financial managers includes resource allocation among current assets, cash, receivable accounts and inventory services or commodities. The major factor that financial managers must consider in managing liquidity is maximization business innovation since the goal that all companies are faced with is to maximize long-term value of the company; at enterprises that tend to move towards receivable accounts and inventory, the profitability of the business unit becomes a priority. This is because ROA and ROE are evaluated based on the efficiency of activities and utilization capacity of the company's operating profits and investments. In the cash conversion cycle, the financial manager works as a professional alongside CEO and has the responsibility of financing and payments needed to manage the company's activities. In addition, when the company makes an investment, the financial manager should make a decision in relation to return of capital and assess whether or not the project is proportional to the amount of investment. A manager has two different roles of ensuring liquidity and profitability. A manager has a role as decision maker and a member of the firm aiming at maximizing long-term value of the company; as the other role and he/she is a specialist in liquidity management at financial and money markets. Liquidity and maximization of corporate value over the long term plays essential role on management of most business organizations. In addition, ROA, ROE, equity multiplier evaluate firms' activities and their operations. Therefore, this paper studies the relationships among these variables according to the size of companies listed in Tehran Stock Exchange.

\section{Literature review}

The empirical studies on relationships among accounts of working capital and cash conversion cycle in US firms were examined based on industry type and the rate of inflation over the period 1969-1983 and a significant relationship was found between cash conversion cycle and the average inventory (Lyroudi \& McCarty, 1993). In addition, the inventory turnover was the largest entry in the cash conversion cycle. Cash conversion cycle and its components did not differ during different courses for different industries but was different from one year to another. Furthermore, there was no significant relationship between the cash conversion cycle and the inflation rate. Factors influencing the level of corporate cash to impact the properties of amount of cash from small business units were studied by Faulkender and Wang (2006) using multiple regression. They reported that, unlike large firms, the amount of cash held increases at small firms with higher leverage. In addition, companies that have a better credit as well as those with a better financial situation hold lesser amounts of cash.

Ferreira and Vilela (2004) studied factors influencing EU funds in Europe to study the causes influencing cash in a sample of firms from Europe Union countries over the period 1987-2000. The results showed that the cash inventory was positively associated with investment opportunities and cash flows, and negatively by the effects of asset liquidity, leverage, and size. Bank debt and existing cash were negatively associated with each other indicating that there was a close banking relationship enabling companies to preserve less cash with the precautionary motive. Lyroudi and McCarty examined the relationship between cash conversion cycle and quick current ratio for American small businesses over the period 2000-2008. The results indicated negative relationships between cash conversion cycle and current ratio, payable accounts period, and inventory conversion period, but there was a positive correlation between the rapid ration and conversion period of receivable accounts. In addition, the results showed that the firms' cash conversion cycles differed in manufacturing, retail and service businesses. Another study showed companies with high-quality financial reporting reduce information asymmetry and a company's cash holding decreases as the bank debt increases, and that larger firms tend to hold more cash (Asadi, 2012). Another survey 
studied the relationship between cash conversion cycle and size of U.S. companies over the period 1981-2010 and examined the connection between cash conversion cycle and other liquidity ratios. The results showed that large commercial firms had shorter cash conversion cycle and that smaller firms should try to manage their cash conversion cycle. In addition, the study showed a positive relationship between cash conversion cycle and the current and quick ratios.

The results of Martínez-Sola et al. (2013) investigated the effect of cash holding on company's value involving 472 accepted industrial companies in the U.S. over the period 2001-2007 and reported that there was an optimal level of cash that makes up $14 \%$ of total assets and the deviation from the optimal cash level reduces a firm's value. Saghir et al. (2011) investigated working capital management and profitability based on evidence from companies in Pakistan, by examining the relationship between profitability and working capital management. They used the information of 60 textile companies in the Karachi Stock Exchange (KSE) over the period 2001-2006 and detected significant relationships between profitability and cash conversion cycle and its components (collection period, payment of debts, and inventory turnover period). They also reported significant negative relationships between cash conversion cycle, receivables collection period, and inventory turnover period.

Hajiha and Faizabadi (2012) investigated the relationship between cash conversion cycle and liquidity ratios of listed companies in Tehran Stock Exchange and reported a positive relationship between cash conversion cycle, and current and quick ratios. Although they reported a positive relationship between cash conversion cycle and quick ratio but the current ratio did not have any relationship with the cash conversion cycle. Additionally, there was a negative causal relationship between the inventory conversion time and cash conversion cycle. Their results indicated that the immediate proportion was a strong representative of the company's liquidity, and that inventory had a negative impact on liquidity. Shafati (2013) investigated the relationship between working capital management and full disclosure of information on 71 companies listed in Tehran Stock Exchange in 8 -year period. The average collection period of receivable accounts and cash conversion cycle were directly correlated with full disclosure of information but they did not find any correlation between the inventory cycle and average payment period of payable accounts with full disclosure of information. Harati (2012) analyzed the greater effect of cash surplus on the firms' stock returns in Tehran Stock Exchange over the period 2000-2008. Six variables related to excess cash profitability, return on equity, future investments, accruals and asset growth were investigated using a comparison test. The findings showed a relationship between the cash surplus, profitability and growth opportunities.

\section{The proposed method}

\subsection{Research hypotheses}

According to the research questions, the following hypotheses have been explained:

The main hypothesis: Assets objectivity, return on assets, return on equity, and equity multiplier are all correlated with the cash conversion cycle.

\subsection{Auxiliary hypothesizes:}

1. The assets objectivity is correlated with the cash conversion cycle.

2. Equity multiplier and the cash conversion cycle are correlated.

3. Return on assets is correlated with cash conversion cycle.

4. Return on equity is correlated with the cash conversion cycle.

In this study, using existing methods and theories, it was tried to resolve the problems of objective assets, return on assets, return on equity and equity multiplier involvement with the cash conversion 
cycle at small and large companies, and to improve their situations. Therefore, the present study as an applied research employed correlation and regression, and the study data are initially described and then analyzed. The sample results are generalized to the statistical society. Therefore, the type of inference procedure of the research is descriptive- inductive. The direction of the research design has been the investigation of post events based on the customers' past information.

\subsection{Sampling}

The statistical population of the current study consisted of selected companies listed in Tehran Stock Exchange, which was used as classified random sampling. In this method, the society is divided into homogeneous classes and each class includes firms with similar characteristics. The samples were then characterized with respect to each class and samples of each class were determined using a systematic sampling method. For determining the sample size, first samples of 15 were randomly selected as the pilot, in which the pilot sample variance was calculated. Afterward, 104 companies were selected based on the original sample size. The performance of these companies has been studied in the period 2008-2012.

\subsection{Methods of analysis}

In order to describe the statistical sample, the samples were described using the descriptive data including three groups of indicators: the core indicators (such as mean and median), measures of dispersion (e.g. variance and standard deviation) and parameters of the distribution (e.g. skewness and elongation indices). The Kolmogorov-Smirnov (KS), Durbin-Watson (DW) and coefficient of determination $\left(\mathrm{R}^{2}\right)$ were applied to analyze the assumptions. Combined linear regression method was used to determine relationships between variables. In addition, the student's t-and Fisher tests were employed to generalize the results.

\subsection{The research model}

In this study, the overall relationships between the cash cycle with the objectivity of assets, return on assets, equity multiplier, and return on equity have been evaluated. Table 1 describes the defined and calculated variables used in this assessment.

\section{Table 1}

Definitions and measurements of variables

\begin{tabular}{|c|c|c|c|}
\hline Measurement & Class & Description of variable & Code \\
\hline Accounts Receivables & \multirow[t]{2}{*}{ Independent } & \multirow[t]{2}{*}{ Period of access claims } & \multirow[t]{2}{*}{$\mathrm{AC}(1)$} \\
\hline Sales $* 365$ & & & \\
\hline Inventory & \multirow[t]{2}{*}{ Independent } & \multirow[t]{2}{*}{ Inventory period } & \multirow[t]{2}{*}{ NO of Days Inventory(2) } \\
\hline$\overline{\text { Cost of Goods Sold * } 365}$ & & & \\
\hline Accounts Payables & \multirow[t]{2}{*}{ Independent } & \multirow[t]{2}{*}{ payable account period } & \multirow[t]{2}{*}{ NO of Days $\mathrm{A} / \mathrm{P}(3)$} \\
\hline$\overline{\text { Cost of Goods Sold } * 365}$ & & & \\
\hline $1+2+3$ & Independent & Cash conversion cycle & Cash Conversion Cycle \\
\hline$P P E_{i, t}$ & \multirow[t]{2}{*}{ Dependent } & \multirow[t]{2}{*}{ Assets objectivity } & \multirow[t]{2}{*}{ Tangible Asset } \\
\hline$\overline{\text { Total Asset }_{i, t}}$ & & & \\
\hline$\underline{N I}$ & \multirow[t]{2}{*}{ Dependent } & \multirow[t]{2}{*}{ Return on assets } & ROA \\
\hline $\begin{array}{l}T A \\
N I\end{array}$ & & & \multirow{2}{*}{$\mathrm{ROE}$} \\
\hline$\overline{S H E}$ & Dependent & Return on equity & \\
\hline$T A$ & \multirow[t]{2}{*}{ Dependent } & \multirow[t]{2}{*}{ Equity ratio } & \multirow[t]{2}{*}{ Equity Multiplier } \\
\hline$\overline{S H E}$ & & & \\
\hline Logarithm of Assets & Control & Company size & Size \\
\hline
\end{tabular}

In this study, the logarithm of assets is considered as a measure of size. Companies greater than the median are considered as large corporations, and those smaller than the median as small firms. The 
relationships between variables were estimated using combined linear regression and the following linear relationships have been applied:

Relationship of cash cycle with the objectivity of assets:

Tangible Asset $_{i t}=b_{0}+b_{1} \mathrm{CCC}_{i t}+b_{2}$ size $_{i t}+\varepsilon_{i t}$

Relationship of cash cycle with equity multiplier:

Equity Multiplier $_{i t}=b_{0}+b_{1} \mathrm{CCC}_{i t}+b_{2}$ size $_{i t}+\varepsilon_{i t}$

Relationship of cash cycle with return on assets:

$\mathrm{ROA}_{i t}=b_{0}+b_{1} \mathrm{CCC}_{i t}+b_{2}$ size $_{i t}+\varepsilon_{i t}$

Relationship of cash cycle with return on equity:

$\mathrm{ROE}_{i t}=b_{0}+b_{1} \mathrm{CCC}_{i t}+b_{2}$ size $_{i t}+\varepsilon_{i t}$

\section{Findings}

The research objective was to assess the relationships between assets, return on assets, return on equity and equity multiplier with the cash conversion cycle in large and small corporations. This research was conducted over the period 2006-2012, in which the statistical population (total companies) obtained from 252 companies giving rise to a sample of 105 companies. The total number of observations in these years was 630 consisting of 306 large and 324 small companies. The dependent variables used in this research included the assets objectivity, return on assets, return on equity, and company's equity multiplier; the cash conversion cycle, and small and large companies were taken as independent variables. In this section, descriptions and analyses of the assumptions and findings are presented.

\subsection{Description of the findings}

Statistical calculations in details based on large and small companies are presented in the survey report. In our survey, all the variables were 324 companies - year at large companies and in small companies, they equaled with 306 companies -year. The average cash conversion cycle for small companies was less than 0.00207. A comparison between large and small companies showed that small firms had lower cash cycle. Comparison of cash cycle variation between big and small firms implied less dispersion among small companies. Skewness coefficients of the variables indicated that, among the research variables, equity multiplier had the greatest left-ward skewness $(-15.505)$ at small firms. Finally, small firms had less cash in circulation ranging between 0.0 and 0.0129 .

\subsection{Analysis of defaults}

Linear regression was used for all the relationships among variables, for which the assumptions of the normal distribution of variables were assessed in advance. To perform regression analysis, first the normality of the variables was studied by the K-S test. Results of the evaluation (Significance levels) are summarized in Table 2.

\section{Table 2}

Kolmogorov-Smirnov test (K-S)

\begin{tabular}{lllllll}
\hline Firms Group & Cash Flow cycle & Tangible Assets & Ownership Ratio & ROA & ROE & Size \\
\hline Small firms & 0 & 0 & 0 & 0.001 & 0 & 0 \\
Big Firms & 0 & 0,018 & 0 & 0,002 & 0 & 0,004 \\
\hline
\end{tabular}

Since the significance level of the variables is smaller than $0.05, \mathrm{H}_{0}$ is rejected and $\mathrm{H}_{1}$ is accepted. The data are not normally distributed. To normalize the variables, mathematical conversion (Log. 2) was used. After logarithmic transformation of variables, normality of the variables was tested and the results are summarized in Table 3. 
Table 3

Kolmogorov-Smirnov test (K-S) (the transformed values)

\begin{tabular}{lllllll}
\hline Firms Group & Cash Flow cycle & Tangible Assets & Ownership Ratio & ROA & ROE & Size \\
\hline Small firms & 0,123 & 0,051 & 0,071 & 0,067 & 0,76 & 0,091 \\
Big Firms & 0,097 & 0,061 & 0,073 & 0,098 & 0,082 & 0,091 \\
\hline
\end{tabular}

In Table 3, the significance level of the variables is higher than 0.05 , therefore, $\mathrm{H}_{0}$ is accepted and $\mathrm{H}_{1}$ is rejected; the data are hence normally distributed. One of the assumptions of regression is independent errors. When the assumption of independent errors is rejected and the errors are correlated with each other, there is not the possibility of regression application. The Durbin-Watson (DW) test examines the independency of errors verifying that a range of 1.5 to 2.5 assumedly rejects the correlation between the errors and that the regression can be used and they are shown in Table4.

Table 4

Independency of errors

\begin{tabular}{lcccccccc}
\hline Model No. & 1 & 2 & 3 & 4 & 5 & 6 & 7 & 8 \\
\hline DW & 1.752 & 1.766 & 1.653 & 1.968 & 1.874 & 1.957 & 1.997 & 2.001 \\
Independent errors & $\sqrt{ }$ & $\sqrt{ }$ & $\sqrt{ }$ & $\sqrt{ }$ & $\sqrt{ }$ & $\sqrt{ }$ & $\sqrt{ }$ & $\sqrt{ }$ \\
\hline
\end{tabular}

As seen in Table 4, Durbin-Watson test is between 1.5 and 2.5, i.e. the acceptance range in all models. In all cases, the assumption of lacking self-correlation or independency of errors is accepted. Among other assumptions is normal distribution of errors in regression estimation evaluated depending on the model:

Models One and Two: The relationship between the cash conversion cycle at large companies with the objectivity of assets: The models shown in Fig. 1 and Fig. 2 indicate distribution estimation errors in comparison with the normal distribution:

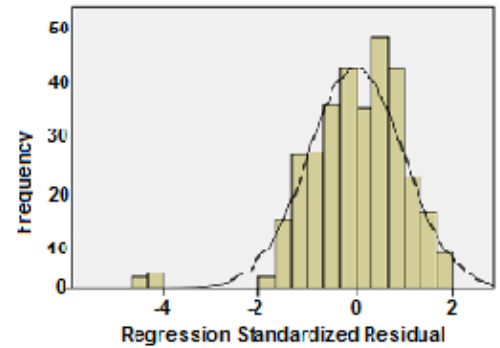

Fig. 1. Distribution of errors for Tangible assets (big firms)

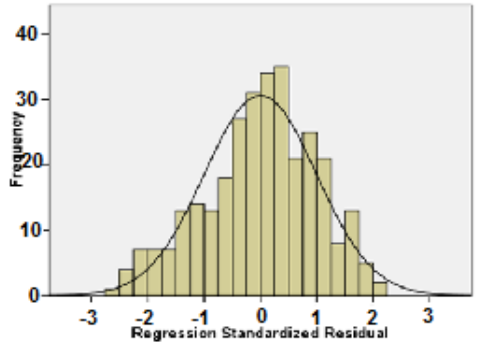

Fig. 2. Distribution of errors for Tangible assets (small firms)

In order for the errors to be normally distributed, the regression errors must be normally distributed with a mean of zero, i.e. Mean $=0, S t d . D e v=.997$ shown in the above diagram on the right. Having this assumption, the regression can be applied on the two variables, the cash conversion cycle in big and small companies with the objectivity of assets. Stability of variances for variables based on data scattering plot is as in Fig. 3 and Fig. 4.

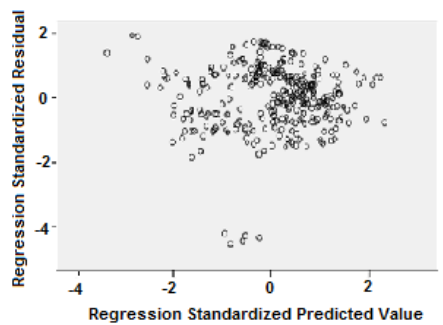

Fig. 3. Distribution of tangible assets (Large firms)

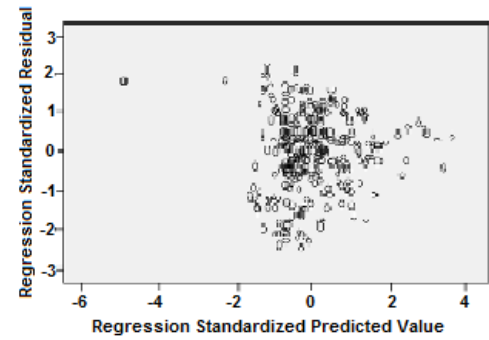

Fig. 4. Distribution of tangible assets (Small firms) 
Fig. 3 and Fig. 4 show the distribution of the data does not follow a specific pattern. Thus, the stability of the variance on both variables will be accepted.

Models Three and Four: the relationship between the cash conversion cycle in small and large companies with equity multiplier: Fig. 5 and Fig. 6 display the comparison between the normal curve and distribution of estimated model error.

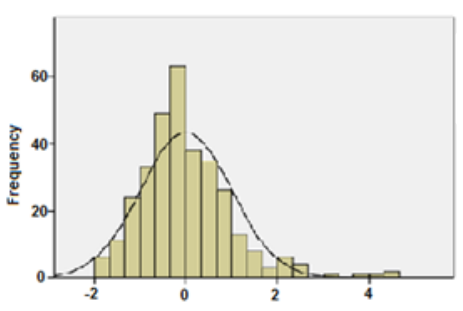

Fig. 4. Distribution of errors for Equity multiplier (big firms)

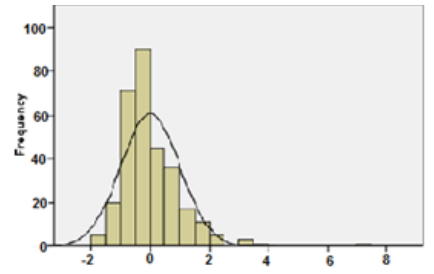

Fig. 5. Distribution of errors for Equity multiplier (small firms)

Fig. 5 and Fig. 6 verify the normality of the errors as another regression assumption. In order for the errors to be normally distributed, the regression errors must be normally distributed with a mean of zero, i.e. Mean $=0$, Std. Dev $=.997$. Having this assumption, the regression can be applied on the two variables, the cash conversion cycle in big and small companies with the objectivity of assets. Stability of variances for variables based on data scattering plot is as in Fig. 7 and Fig. 8.

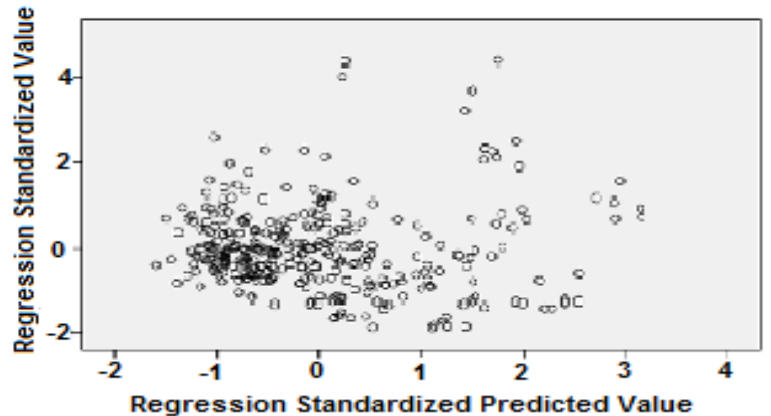

Fig. 7. Distribution of Equity multiplier (Large firms)

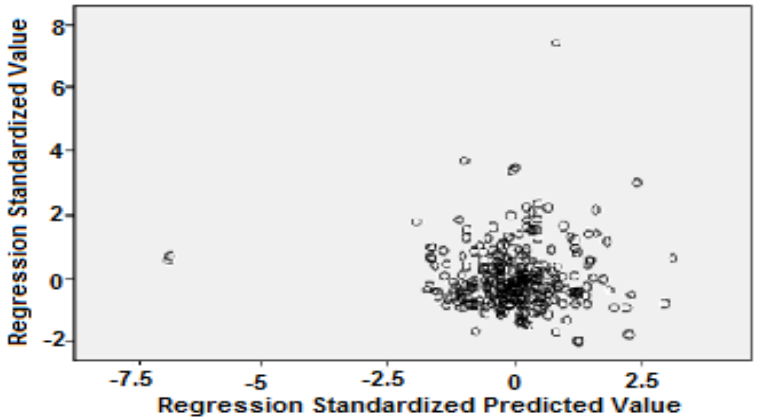

Fig. 8. Distribution of Equity multiplier (Small firms)

Fig. 7 and Fig. 8 show the distribution of the data does not follow a specific pattern; hence, the stability of the variances is established.

Models Five and Six: the relationship between the cash conversion cycle in small and large companies with equity multiplier: Fig. 9 and Fig. 10 display the comparison between the normal curve and distribution of estimated model error.

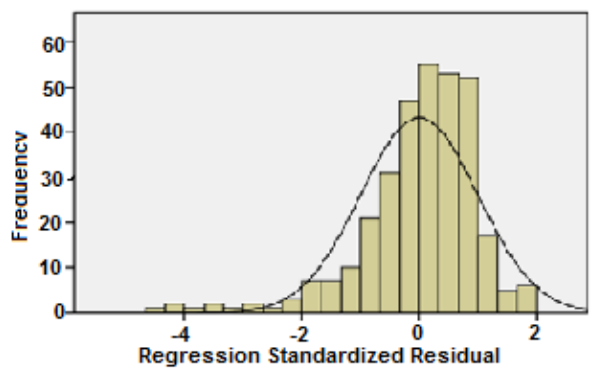

Fig. 9. Distribution of errors for ROA (big firms)

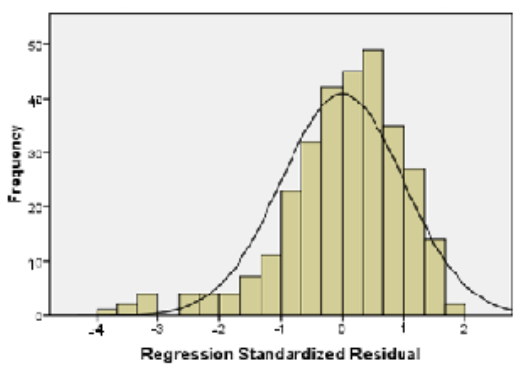

Fig. 10. Distribution of errors for ROA (small firms) 
In these diagrams we have: Mean $=0$, Std. Dev $=.997$. Having this assumption, the regression can be used for the two variables of cash conversion cycle in both large and small firms with asset returns. Furthermore, the stability of the variances in the dependent variable is based on the distribution Fig. 11 and Fig. 12.

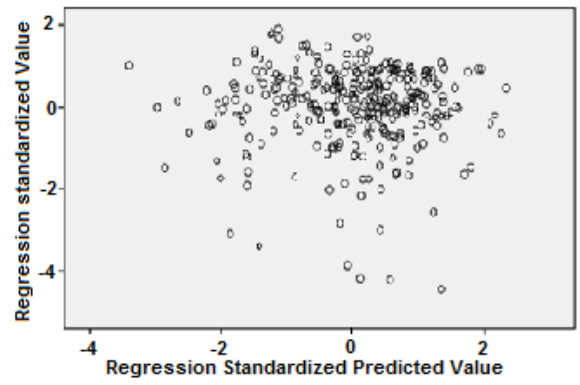

Fig. 11. Distribution of ROA (Large firms)

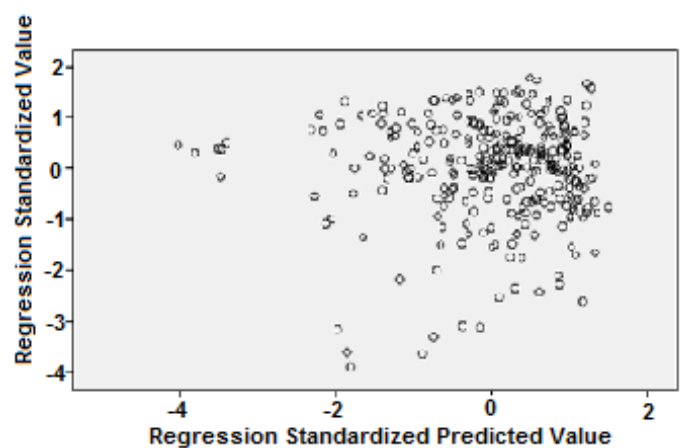

Fig. 12. Distribution of ROA (Small firms)

Based on Fig. 11 and Fig. 12, the distribution of the dependent variables does not follow a certain pattern. Therefore, we can assume that the variances in the dependent variables were stable.

Models Seven and Eight: the relationship between the cash conversion cycle in small and large companies with a return on equity: Error distribution models compared with the normal distribution curve is shown in Fig. 13 and Fig. 14.

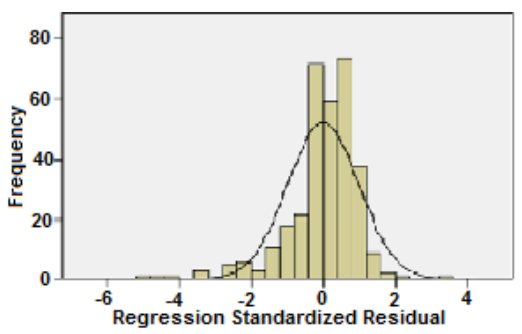

Fig. 13. Distribution of errors for ROE (big firms)

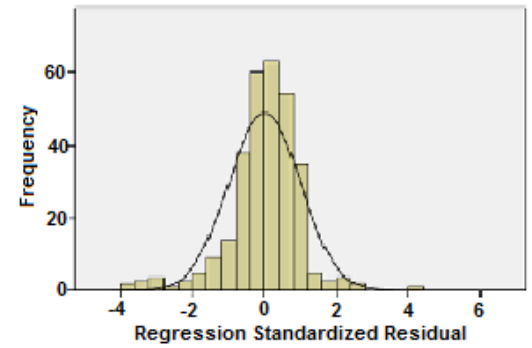

Fig. 14. Distribution of errors for ROE (small firms) Fig. 13 and Fig. 14 illustrate another regression assumption of normality of errors. Under this assumption, the regression errors are normally distributed with a mean of zero Mean $=0$, Std.Dev $=.997$ shown in the above, right diagram. Having this assumption, the regression can be used for the two variables of cash conversion cycle in both large and small firms with return on equity. Furthermore, the stability of the variances in the dependent variable is based on the distribution diagram of the Fig. 15 and Fig. 16.

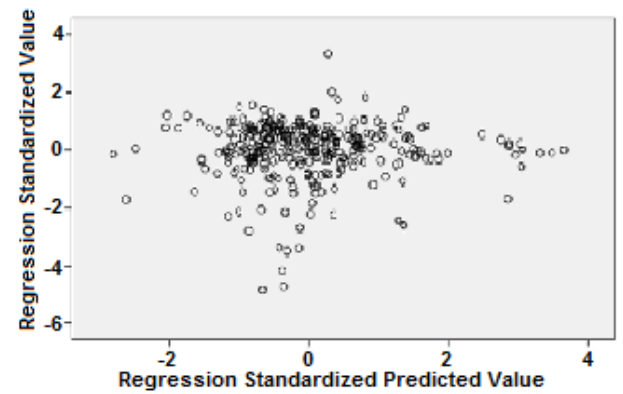

Fig. 15. Distribution of ROE (Large firms)

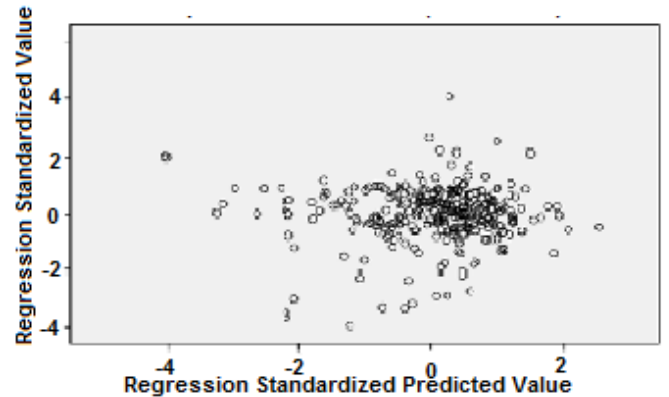

Fig. 16. Distribution of ROE (Small firms) 
According to Fig. 15 and Fig. 16, the distribution of the dependent variables does not follow a certain pattern. Therefore, it can be assumed that the variances in the independent variables were stable.

\subsection{Analyzing the relationship between the variables}

Assumptions of the composite linear regression were studied in the previous section. Using this method, the relationship between the independent variables and the cash cycle in large and small firms was separately estimated. The results estimated relationships between variables of large and small firms using combined linear regression are summarized in Table 5.

\section{Table 5}

Estimates of the relationship between variables

\begin{tabular}{|c|c|c|c|c|}
\hline Fisher & $\mathrm{R}^{2}$ & Sig. & Regression Model & Relation \\
\hline 4,77 & 0,329 & $0,000^{\mathrm{a}}$ & Tangible Asset $_{i t}=5.874-.187 *$ CCC $_{i t}-2.002 *$ size $_{i t}$ & $\begin{array}{l}\text { Cash Conversion Cycle and tangible } \\
\text { assets in large firms }\end{array}$ \\
\hline 32,115 & 0,375 & $0,000^{\mathrm{a}}$ & $\begin{aligned} \text { Tangible Asset }_{i t}= & 11.855-.219 * \mathrm{CCC}_{i t}-3.553 \\
& * \text { size }_{i t}\end{aligned}$ & $\begin{array}{l}\text { Cash Conversion Cycle and tangible } \\
\text { assets in small firms }\end{array}$ \\
\hline 6.262 & 0,338 & $0,000^{\mathrm{a}}$ & $\begin{array}{c}\text { Equity Multiplier }_{i t}=-6.213+.219 * \mathrm{CCC}_{i t}+1.670 \\
* \text { size }_{i t}\end{array}$ & $\begin{array}{l}\text { Cash Conversion Cycle and equity } \\
\text { multiplier in large firms }\end{array}$ \\
\hline 11,663 & 0,371 & $0,000^{\mathrm{a}}$ & $\begin{array}{c}\text { Equity Multiplier }_{i t}=-6.508+.166 * \mathrm{CCC}_{i t}+1.314 \\
* \text { size }_{i t}\end{array}$ & $\begin{array}{l}\text { Cash Conversion Cycle and equity } \\
\text { multiplier in small firms }\end{array}$ \\
\hline 4,186 & 0,494 & $0,000^{\mathrm{a}}$ & $\mathrm{ROA}_{i t}=-9.336+.439 * \mathrm{CCC}_{i t}-.840 *$ size $_{i t}$ & $\begin{array}{l}\text { Cash Conversion Cycle and ROA in } \\
\text { large firms }\end{array}$ \\
\hline 4,121 & 0,512 & $0,000^{\mathrm{a}}$ & $\mathrm{ROA}_{i t}=-15.272+.320 * \mathrm{CCC}_{i t}+2.069 *$ size $_{i t}$ & $\begin{array}{l}\text { Cash Conversion Cycle and ROA in } \\
\text { small firms }\end{array}$ \\
\hline 3,79 & 0.505 & $0,000^{\mathrm{a}}$ & $\operatorname{ROE}_{i t}=-7.512+.221 * \operatorname{CCC}_{i t}+.821 *$ size $_{i t}$ & $\begin{array}{l}\text { Cash Conversion Cycle and ROE in large } \\
\text { firms }\end{array}$ \\
\hline 6,599 & 0.442 & $0,000^{\mathrm{a}}$ & $\mathrm{ROE}_{i t}=-22.062+.185 * \mathrm{CCC}_{i t}+3$ & $\begin{array}{l}\text { Cash Conversion Cycle and ROE in } \\
\text { small firms }\end{array}$ \\
\hline
\end{tabular}

\subsubsection{The relationship between the assets objectivity with the cash flow}

Considering that the estimated coefficients on the relationship between large and small companies with the assets objectivity are equal to 0.329 and 0.375 , respectively and there is a poor linear relationship between the variables. These values are significant (Sig. $=0.05$ ) demonstrating significant relations between the two variables of assets objectivity with the cash conversion cycle in large companies. The negative coefficient of the variable in the estimated equation indicates that the assets objectivity and the cash cycle in big and small enterprises are inversely related.

Table 7

Regression coefficients for the independent and control variables at large corporations

\begin{tabular}{|c|c|c|c|c|c|c|}
\hline \multirow{2}{*}{\multicolumn{2}{|c|}{ Model }} & \multicolumn{2}{|c|}{ Unstandardized Coefficients } & \multirow{2}{*}{$\begin{array}{l}\text { Standardized Coefficients } \\
\text { Beta }\end{array}$} & \multirow[b]{2}{*}{$\mathrm{t}$} & \multirow[b]{2}{*}{ Sig. } \\
\hline & & $\mathrm{B}$ & Std. Error & & & \\
\hline \multirow[t]{3}{*}{1} & (Constant) & 5.874 & 4.152 & & 1.415 & .158 \\
\hline & Cash Conversion Cycle & -.187 & .045 & -.306 & -4.155 & .006 \\
\hline & Size & -2.002 & .778 & -.142 & -2.572 & .011 \\
\hline
\end{tabular}

Dependent Variable: Tangible Asset

\section{Table 8}

Regression coefficients for the independent and control variables at small corporations

\begin{tabular}{|c|c|c|c|c|c|c|}
\hline \multirow{2}{*}{\multicolumn{2}{|c|}{ Model }} & \multicolumn{2}{|c|}{ Unstandardized Coefficients } & \multirow{2}{*}{$\begin{array}{l}\text { Standardized Coefficients } \\
\text { Beta }\end{array}$} & \multirow[b]{2}{*}{$\mathrm{t}$} & \multirow[b]{2}{*}{ Sig. } \\
\hline & & $\mathrm{B}$ & Std. Error & & & \\
\hline \multirow[t]{3}{*}{1} & (Constant) & 11.855 & 3.382 & & 3.505 & .001 \\
\hline & Cash Conversion Cvcle & -.219 & .043 & -.270 & -5.137 & .000 \\
\hline & Size & -3.553 & .651 & -.287 & -5.461 & .000 \\
\hline
\end{tabular}

a. Dependent Variable: Tangible Asset

In Tables 7 and 8 (column B) the constant values and coefficients of the independent variables in the regression equation are presented, which as follows, 
Tangible Asset $_{i t}=5.874-.187 * \mathrm{CCC}_{i t}-2.002 *$ size $_{i t}$

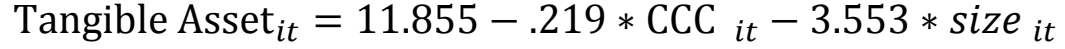

In Tables 7 and 8, the other columns contain the standard coefficients of column B, the t-statistic, and significance in order to test the hypothesis of equality for each coefficient in column B with a value of zero. Because of this output $(\mathrm{Sig}=0)$ the test of regression coefficient equality and constant value equal to zero $(<0.05)$, hence, the assumption of a linear relationship is accepted.

\subsubsection{The relationship between equity multiplier with cash conversion cycle in big and small firms}

Considering that the estimated coefficients on the relationship between large and small companies with the equity multiplier are equal to 0.338 and 0.371 , respectively, there is a poor linear relationship between the variables. These values are significant at $\mathrm{p}=0.05$ demonstrating significant relations between the two variables of equity multiplier with the cash conversion cycle in large companies. The positive coefficient of the variable in the estimated equation indicates that the equity multiplier and the cash cycle in big and small enterprises are directly related.

\section{Table 9}

$\underline{\text { Regression coefficients for the independent and control variables at large corporations }}$

\begin{tabular}{|c|c|c|c|c|c|c|}
\hline \multirow[b]{2}{*}{ Mode } & & \multicolumn{2}{|c|}{ Unstandardized Coefficients } & \multirow{2}{*}{$\begin{array}{l}\text { Standardized Coefficients } \\
\text { Beta }\end{array}$} & \multirow[b]{2}{*}{$\mathrm{t}$} & \multirow[b]{2}{*}{ Sig. } \\
\hline & & $\mathrm{B}$ & Std. Error & & & \\
\hline \multirow[t]{3}{*}{1} & (Constant) & -6.213 & 2.536 & & -2.450 & .015 \\
\hline & Cash Conversion Cvcle & .219 & .028 & .338 & 7.821 & .000 \\
\hline & Size & 1.670 & .475 & .193 & 3.516 & .001 \\
\hline
\end{tabular}

a. Dependent Variable: equity Multiplier

In Table 9 and Table 10 (column B) the constant values and coefficients of the independent variables in the regression equation are presented, which are as follows:

Equity Multiplier $_{i t}=-6.213+.219 * \mathrm{CCC}_{i t}+1.670 *$ size $_{i t}$

Equity Multiplier $_{i t}=-6.508+.166 * \mathrm{CCC}_{i t}+1.314 *$ size $_{i t}$

\section{Table 10}

Regression coefficients for the independent and control variables at small corporations

\begin{tabular}{|c|c|c|c|c|c|c|}
\hline \multirow[b]{2}{*}{ Mode } & & \multicolumn{2}{|c|}{ Unstandardized Coefficients } & \multirow{2}{*}{$\begin{array}{l}\text { Standardized Coefficients } \\
\text { Beta }\end{array}$} & \multirow[b]{2}{*}{$\mathrm{t}$} & \multirow[b]{2}{*}{ Sig. } \\
\hline & & $\mathrm{B}$ & Std. Error & & & \\
\hline \multirow[t]{3}{*}{1} & (Constant) & -6.508 & 2.936 & & -2.217 & .027 \\
\hline & Cash Conversion Cvcle & .166 & .037 & .251 & 4.490 & .000 \\
\hline & Size & 1.314 & .565 & .130 & 2.327 & .021 \\
\hline
\end{tabular}

a. Dependent Variable: equity Multiplier

In Tables 9 and 10, the other columns contain the standard coefficients of column B, the t-statistic, and significance in order to test the hypothesis of equality for each coefficient in column B with a value of zero. Because of this output $(\mathrm{Sig}=0)$ the test of regression coefficient equality and constant value equal to zero $(<0.05)$, hence, the assumption of a linear relationship is accepted.

\subsubsection{The relationship between return on assets and cash conversion cycle at large and small firms}

Considering that the estimated coefficients on the relationship between large and small companies with the return on assets are equal to 0.494 and 0.512 , respectively, there is a poor linear relationship between the variables. These values are significant at $\mathrm{p}=0.05$ demonstrating significant relations between the two variables of return on assets with the cash conversion cycle in large companies. The positive coefficient of the variable in the estimated equation indicates that the return on assets and the cash cycle in big and small enterprises are directly related. 
Table 11

Regression coefficients for the independent and control variables at large corporations

\begin{tabular}{|c|c|c|c|c|c|c|}
\hline \multirow{2}{*}{\multicolumn{2}{|c|}{ Model }} & \multicolumn{2}{|c|}{ Unstandardized Coefficients } & \multirow{2}{*}{$\begin{array}{l}\text { Standardized Coefficients } \\
\text { Beta }\end{array}$} & \multirow[b]{2}{*}{$\mathrm{t}$} & \multirow[b]{2}{*}{ Sig. } \\
\hline & & $\mathrm{B}$ & Std. Error & & & \\
\hline \multirow[t]{3}{*}{1} & (Constant) & -9.336 & 4.864 & & -1.919 & .014 \\
\hline & Cash Conversion Cvcle & .439 & .053 & .441 & 8.283 & .000 \\
\hline & Size & -.840 & .912 & -.051 & -.921 & .358 \\
\hline
\end{tabular}

a. Dependent Variable: ROA

Table 12

Regression coefficients for the independent and control variables at small corporations

\begin{tabular}{|c|c|c|c|c|c|c|}
\hline \multirow{2}{*}{\multicolumn{2}{|c|}{ Model }} & \multicolumn{2}{|c|}{ Unstandardized Coefficients } & \multirow{2}{*}{$\begin{array}{c}\text { Standardized Coefficients } \\
\text { Beta } \\
\end{array}$} & \multirow[b]{2}{*}{$\mathrm{t}$} & \multirow[b]{2}{*}{ Sig. } \\
\hline & & $\mathrm{B}$ & Std. Error & & & \\
\hline \multirow[t]{3}{*}{1} & (Constant) & -15.272 & 5.758 & & -2.652 & .008 \\
\hline & Cash Conversion Cycle & .320 & .073 & .316 & 4.383 & .000 \\
\hline & Size & 2.069 & 1.108 & .108 & 1.868 & .063 \\
\hline
\end{tabular}

a. Dependent Variable: ROA

In Tables 11 and 12 the coefficients of the independent variables in the regression equation are presented. These equations for large and small firms, respectively, are as follows:

$\mathrm{ROA}_{i t}=-9.336+.439 * \mathrm{CCC}_{i t}-.840 *$ size $_{i t}$

$\mathrm{ROA}_{i t}=-15.272+.320 * \mathrm{CCC}_{i t}+2.069 *$ size $_{i t}$

In Tables 11 and 12, the other columns contain the standard coefficients of column B, the t-statistic, and significance in order to test the hypothesis of equality for each coefficient in column B with a value of zero. Because of this output $(\mathrm{Sig}=0)$ the test of regression coefficient equality and constant value equal to zero $(<0.05)$, hence, the assumption of a linear relationship is accepted.

\subsubsection{The relationship between return on equity and cash conversion cycle at large and small firms}

Considering that the estimated coefficients on the relationship between large and small companies with the return on assets are equal to 0.505 and 0.442 , respectively, there is a moderate linear relationship between the variables. These values are significant at $\mathrm{p}=0.05$ demonstrating significant relations between the two variables of return on equity with the cash conversion cycle in large companies. The positive coefficient of the variable in the estimated equation indicates that the return on equity and the cash cycle in big and small enterprises are directly related.

Table 13

Regression coefficients for the independent and control variables at large corporations

\begin{tabular}{|c|c|c|c|c|c|c|}
\hline \multirow{2}{*}{\multicolumn{2}{|c|}{ Model }} & \multicolumn{2}{|c|}{ Unstandardized Coefficients } & \multirow{2}{*}{$\begin{array}{l}\text { Standardized Coefficients } \\
\text { Beta }\end{array}$} & \multirow[b]{2}{*}{$\mathrm{t}$} & \multirow[b]{2}{*}{ Sig. } \\
\hline & & $\mathrm{B}$ & Std. Error & & & \\
\hline \multirow[t]{3}{*}{1} & (Constant) & -7.512 & 4.062 & & -1.849 & .045 \\
\hline & Cash Conversion Cvcle & .221 & .044 & .426 & 5.022 & .000 \\
\hline & Size & .821 & .761 & .060 & 1.079 & .282 \\
\hline
\end{tabular}

a. Dependent Variable: ROE

\section{Table 14}

Regression coefficients for the independent and control variables at small corporations

\begin{tabular}{lllllll}
\hline & & \multicolumn{2}{l}{ Unstandardized Coefficients } & \multicolumn{2}{l}{ Standardized Coefficients } \\
Model & & $\mathrm{B}$ & Std. Error & Beta & $\mathrm{t}$ & Sig. \\
\hline 1 & (Constant) & -22.062 & 5.555 & & -3.971 & .000 \\
& Cash Conversion Cycle & .185 & .070 & .157 & 2.642 & .009 \\
& Size & 3.440 & 1.068 & .182 & 3.220 & .001 \\
\hline
\end{tabular}


In Table 13 and Table 14, the constant values and coefficients of the regression function are presented and Eq. (9) and Eq. (10) show the results for large and small firms, respectively,

$\mathrm{ROE}_{i t}=-7.512+.221 * \mathrm{CCC}_{i t}+.821 *$ size $_{i t}$

$\mathrm{ROE}_{i t}=-22.062+.185 * \mathrm{CCC}_{i t}+3.440 *$ size $_{i t}$

In Tables 13 and 14, the other columns contain the standard coefficients of column B, the t-statistic, and significance in order to test the hypothesis of equality for each coefficient in column B with a value of zero. Because of this output $(\mathrm{Sig}=0)$ the test of regression coefficient equality and constant value equal to zero $(<0.05)$, hence, the assumption of a linear relationship is accepted.

\section{Conclusion}

This paper has studied the effects of cash conversion cycle (CCC) and size of selected firms listed on Tehran Stock Exchange (TSE) on four variables including return of assets, return of equities, tangible assets and equity multiplier. The study has selected a sample of 105 firms listed on TSE and it has divided them into two groups of big and small sized companies over the period 2008-2012. Using a regression analysis, the study confirmed a meaningful relationship between different variables. In other words, CCC and size negatively influence on tangible assets, positively influence on equity multiplier as well as ROA but the effects of CCC and size on ROE for small and big firms are mixed.

\section{References}

Asadi, I. (2011). A study on the effect of over-investment on the reaction of investors to cash holdings. MSc Thesis, Arak Islamic Azad University.

Brigham, E., \& Houston, J. (2011). Fundamentals of financial management. Cengage Learning.

Drobetz, W., Grüninger, M. C., \& Hirschvogl, S. (2010). Information asymmetry and the value of cash. Journal of Banking \& Finance, 34(9), 2168-2184.

Ferreira, M. A., \& Vilela, A. S. (2004). Why do firms hold cash? Evidence from EMU countries. European Financial Management, 10(2), 295-319.

Faulkender, M., \& Wang, R. (2006). Corporate financial policy and the value of cash. The Journal of Finance, 61(4), 1957-1990.

Hajiha, Z., \& Feizabadi, F. (2012). Exploring the relationship between cash conversion cycle and liquidity ratios of listed companies in Tehran Stock Exchange. Quarterly Journal of Industrial Management, Faculty of Humanities, Islamic Azad University of Sanandaj- $6^{\text {th }}$ Year / Issue 18.

Harati, H. (2012). The effect of cash surplus on stock returns. MSc thesis, International University of Imam Khomeini.

Lyroudi, K., \& Lazaridis, Y. (2000). The cash conversion cycle and liquidity analysis of the food industry in Greece.

Lyroudi, K., \& McCarty, D. (1993). An empirical investigation of the Cash Conversion Cycle of small business firms. Journal of Small Business Finance, 2(2), 139-161.

Martínez-Sola, C., García-Teruel, P. J., \& Martínez-Solano, P. (2013). Corporate cash holding and firm value. Applied Economics, 45(2), 161-170.

Moss, J. D., \& Stine, B. (1993). Cash conversion cycle and firm size: a study of retail firms. Managerial Finance, 19(8), 25-34.

Shafati, Z. (2013). Relationship between working capital management and full disclosure of information in the Tehran Stock Exchange. Master's Thesis.

Raheman, A., \& Nasr, M. (2007). Working capital management and profitability-case of Pakistani firms. International review of business research papers, 3(1), 279-300.

Saghir, A., Hashmi, F. M., Hussain, M.N. (2011). Working capital management and profitability: Evidence from Pakistan firms. International Journal of Contemporary Research in Business, 3(8), 1092-1105. 